\title{
Low-Intensity Continuous Ultrasound for the Symptomatic Treatment of Upper Shoulder and Neck Pain: A Randomized, Double-Blind Placebo-Controlled Clinical Trial [Corrigendum]
}

Petterson S, Plancher K, Klyve D, Draper D, Ortiz R. J Pain Res. 2020;13:1277-1287.

Page 1277, Abstract, Results, second sentence, the text "Participants treated with active therapy observed a significant mean pain reduction from baseline of 2.61 points for active $(\mathrm{p}<0.001)$, compared to 1.58 points decrease from baseline for placebo $(p=0.087)$, resulting in a 1.03 points significant decrease in the active group over placebo $(p=0.003)$ " should read "Participants treated with active therapy observed a significant mean pain reduction from baseline of 2.61 points for active $(\mathrm{p}<0.001)$, compared to 1.58 points decrease from baseline for placebo $(\mathrm{p}=0.087)$, resulting in a 1.03 points significant decrease in the active group over placebo $(p=0.009)$ ".

Page 1281, Results, Pain Change from Baseline section, last sentence, the text "While this could indicate a placebo effect, the difference between groups for change from baseline was significant for all 4 weeks assessed ( $p<0.001$ for weeks $1-3, p=0.003$ for week 4 ), showing a more significant change from baseline for the active LICUS group compared to placebo" should read "While this could indicate a placebo effect, the difference between groups for change from baseline was significant for all 4 weeks assessed $(p<0.001$ for weeks $1-2, p<0.01$ for weeks 3-4), showing a more significant change from baseline for the active LICUS group compared to placebo".

Page 1282, Table 2 is incorrect. The correct table is shown below.

The authors apologize for these errors and advise they do not affect the results of the paper.

Table 2 Primary Outcomes. The Pain Reported at Baseline and Weekly Averages. Change in Pain from Baseline and Comparison Between Groups Evaluated Using Independent $t$-tests

\begin{tabular}{|c|c|c|c|c|}
\hline \multicolumn{5}{|c|}{ Pain diary data (NRS) } \\
\hline Time & Active & Placebo & Between Group Mean 95\% Cl & P-value \\
\hline Baseline & $5.60 \pm 1.58$ & $5.44 \pm 1.95$ & $0.163(-1.22$ to 1.55$)$ & 0.81 \\
\hline Week I & $3.54 \pm 1.64$ & $4.58 \pm 2.20$ & $-1.03(-1.65$ to -0.42$)$ & 0.001 \\
\hline Week 2 & $3.26 \pm 1.58$ & $4.74 \pm 2.39$ & $-1.48(-2.12$ to -0.84$)$ & $<0.001$ \\
\hline Week 3 & $3.09 \pm 1.54$ & $3.92 \pm 2.10$ & $-0.827(-1.46$ to -0.19$)$ & 0.011 \\
\hline Week 4 & $2.98 \pm 1.62$ & $3.86 \pm 2.30$ & $-0.87(-1.64$ to -0.106$)$ & 0.026 \\
\hline \multicolumn{5}{|c|}{ NRS mean change from baseline $95 \% \mathrm{CI}$} \\
\hline Week I & $\begin{array}{l}-2.05 \pm 1.64 \\
-2.76 \text { to }-1.35 \\
\mathrm{P}<0.001\end{array}$ & $\begin{array}{l}-0.860 \pm 2.21 \\
-2.53 \text { to } 0.81 \\
p=0.306\end{array}$ & $-1.20(-1.81$ to -0.579$)$ & $<0.001$ \\
\hline Week 2 & $\begin{array}{l}-2.34 \pm 1.59 \\
-3.03 \text { to }-1.65 \\
\mathrm{P}<0.001\end{array}$ & $\begin{array}{l}-0.693 \pm 2.38 \\
-2.49 \text { to } 1.11 \\
p=0.443\end{array}$ & $-1.65(-2.28$ to -1.00$)$ & $<0.001$ \\
\hline
\end{tabular}

(Continued) 
(Continued).

\section{Pain diary data (NRS)}

\begin{tabular}{|l|l|l|l|l|}
\hline Time & Active & Placebo & Between Group Mean 95\% Cl & P-value \\
\hline Week 3 & $-2.51 \pm 1.55$ & $-1.52 \pm 2.11$ & $-0.989(-1.62$ to -0.351$)$ & 0.003 \\
& -3.18 to -1.83 & -3.14 to 0.110 & & \\
& $p<0.001$ & $P=0.07$ & $-1.03(-1.80$ to -0.264$)$ & 0.009 \\
\hline Week 4 & $-2.61 \pm 1.63$ & $-1.58 \pm 2.30$ & & \\
& -3.34 to -1.90 & -3.40 to 0.24 \\
& $P<0.001$ & $P=0.087$ & & \\
\hline
\end{tabular}

Journal of Pain Research

\section{Publish your work in this journal}

The Journal of Pain Research is an international, peer reviewed, open access, online journal that welcomes laboratory and clinical findings in the fields of pain research and the prevention and management of pain. Original research, reviews, symposium reports, hypothesis formation and commentaries are all considered for publication. The manuscript management system is completely online and includes a very quick and fair peer-review system, which is all easy to use. Visit http:// www.dovepress.com/testimonials.php to read real quotes from published authors. 